GRASAS Y ACEITES, 61 (3),

JULIO-SEPTIEMBRE, 261-270, 2010,

ISSN: 0017-3495

DOI: $10.3989 /$ gya.111709

\title{
Hypolipidemic effect of vegetable and cereal dietary mixtures from Egyptian sources
}

\author{
By Magdy M. Rashed, ${ }^{1}$ Magdy Shallan, ${ }^{1}$ Doha A. Mohamed, ${ }^{2, \star}$ \\ Karem Fouda ${ }^{2}$ and Laila M. Hanna ${ }^{2}$
}

\author{
'Biochemistry Department, Faculty of Agriculture, Cairo University, Cairo, Egypt. \\ ${ }^{2}$ Food Sciences and Nutrition Department, National Research Centre, Dokki, Cairo, Egypt. \\ ( ${ }^{\star}$ Corresponding author: dohamohamed@yahoo.com)
}

\section{RESUMEN}

Efecto hipolipidémico de mezclas de verduras y cereales comestibles de procedencia Egipcia.

La hiperlipidemia es un factor de riesgo predominante en la ateroesclerosis y enfermedades cardiovasculares asociadas (CVD). Las directrices Internacionales dictadas por la Organización Mundial de la Salud recomiendan una reducción en la ingesta de grasas saturadas y colesterol como medio para prevenir la hipercolesterolemia y las CVD; sin embargo, solamente hay un número limitado de datos disponibles sobre el beneficio del consumo de verduras en los factores de riesgo de las CVD. El objetivo de este estudio fue preparar dos mezclas en polvo que contenían verduras y cereales. El efecto hypolipidémico de estas dos mezclas fue evaluado en ratas hiperlipidémicas. La primera mezcla fue preparada con trigo, col, perejil y pimiento mientras que la segunda mezcla fue preparada con trigo, remolacha, perejil y pimiento. El trigo fue usado como fuente de fibra, mientras que la col y la remolacha como fuente de glucosinolatos (GLS) y betalinas, respectivamente y fibra también. La composición química de estas mezclas fue determinada. La seguridad de estas muestras fue también evaluada a través de las funciones del hígado y del riñón. La composición química de las mezclas en polvo indica que la mezcla (1) y (2) contienen un $19.1 \%$ y un $13.3 \%$ de proteina, un $2.1 \%$ y un $2.5 \%$ de grasa, un $69.6 \%$ y un $77.5 \%$ de azúcares, un $1.8 \%$ y un $1.2 \%$ de fibra cruda, un $7.4 \%$ y un $5.5 \%$ de cenizas y un $18.3 \%$ y $16.8 \%$ fibra, respectivamente. El contenido de vitamin $E$ fue de 7.4 y $4.5 \mathrm{mg} / 100 \mathrm{~g}$ de mezcla (1) y (2) respectivamente. El contenido de $\beta$-carotene fue de 830 y $786 \mu \mathrm{g} / 100 \mathrm{~g}$ de mezcla (1) y (2) respectivamente. Los compuestos fenólicos totales fueron 1910 y $1710 \mathrm{mg}$ como equivalentes de ácido gálico $/ 100 \mathrm{~g}$ de mezcla (1) y (2) respectivamente. Los resultados de los experimentos con animales mostraron una reducción no significativa en el peso final y en la ganancia de peso en ratas alimentadas con dietas control conteniendo la mezcla (1) y (2) cuando se compara con diferentes grupos. Las ratas alimentadas con dietas control conteniendo mezcla (1) y (2) mostraron una reducción significativa en los lípidos totales del plasma, T-Ch, LDL-Ch, TG y la relación de T-Ch /HDL-Ch con diferentes grados, mientras que HDL-Ch aumento significativamente. Las mezclas estudiadas mostraron un efecto hipolipidémico, que puede ser debido a la presencia de fibra, proteínas de plantas y compuestos fenólicos.

PALABRAS CLAVE: Cereales - Col - Hiperlipidemia Mezclas alimentarias - Remolacha - Verduras.

\section{SUMMARY}

Hypolipidemic effect of vegetable and cereal dietary mixtures from Egyptian sources.

Hyperlipidemia is a predominant risk factor for atherosclerosis and associated cardiovascular diseases (CVD). The international guidelines issued by the World Health Organization recommend a reduction in dietary saturated fat and cholesterol intake as a means to prevent hypercholesterolemia and CVD; however, only limited data are available on the benefits of vegetable consumption on CVD risk factors. The aim of this study was to prepare two powder mixtures containing vegetables and cereals and to evaluate their effect in hyperlipidemic rats. The first mixture was prepared from whole wheat, cabbage, parsley and pepper, while the second mixture was prepared from whole wheat, red beet root, parsley and pepper. Whole wheat was used as a source of dietary fiber, while cabbage and beetroot were used as sources of glucosinolates (GLS) and betalains respectively as well as dietary fiber. The chemical compositions of these mixtures were determined. The safety of these mixtures was also evaluated by examining liver and kidney functions. The chemical compositions of the powder mixtures revealed that mixtures (1) and (2) contain $19.1 \%$ and $13.3 \%$ protein, $2.1 \%$ and $2.5 \%$ fat, $69.6 \%$ and $77.5 \%$ carbohydrates, $1.8 \%$ and $1.2 \%$ crude fibers, $7.4 \%$ and $5.5 \%$ ash and $18.3 \%$ and $16.8 \%$ dietary fibers respectively. Vitamin $\mathrm{E}$ was 7.4 and $4.5 \mathrm{mg} / 100 \mathrm{~g}$ in mixtures (1) and (2) respectively. $\beta$-carotene was 830 and $786 \mu \mathrm{g} / 100 \mathrm{~g}$ in mixtures (1) and (2) respectively. Total phenolic compounds were 1910 and $1710 \mathrm{mg}$ as gallic acid equivalents/100g in mixtures (1) and (2) respectively. The results of the animal experiment showed a non-significant reduction in final body weight and body weight gain in rats fed the control diet containing mixture (1) or (2) when compared with different groups. Rats fed the control diet containing mixture (1) or (2) showed a significant reduction in plasma total lipids, T-Ch, LDL-Ch, TG and the ratio of T-Ch /HDL$\mathrm{Ch}$ in different degrees, while HDL-Ch increased significantly. The studied mixtures showed a hypolipidemic effect, which may be due to the presence of dietary fibers, plant protein, and phenolic compunds.

KEY-WORDS: Beetroot - Cabbage - Cereals - Dietary mixtures - Hyperlipidemia - Vegetables.

\section{INTRODUCTION}

Hyperlipidemia, mainly an increased level of total cholesterol (T-Ch), triglycerides (TG) and low-density lipoprotein cholesterol (LDL-Ch) along with a decrease 
in high-density lipoprotein cholesterol (HDL-Ch), is the predictor of coronary artery disease, fatty liver disease, and carcinogenesis, which is associated with the formation of reactive oxygen species (Roberts et al., 2006). Hyperlipidemia is a predominant risk factor for cardiovascular diseases (CVD) (Deng, 2009). Hyperlipidemia is an important risk factor in the initiation and progression of atherosclerotic impasse (Harrison et al., 2003). A high cholesterol diet increases serum LDL levels and oxidative stress which results in increased oxidized LDL levels and thereby increases atherosclerotic plaque formation (Warnholtz et al., 2001). Therefore, a prime consideration in the therapy for hyperlipidemia and atherosclerosis is to attenuate the elevated blood serum/plasma levels of lipids. The standard international guidelines issued by the World Health Organization recommend reductions in dietary saturated fat and cholesterol intake as means to prevent hypercholesterolemia; however, only limited data are available on the benefits of fruit and vegetable consumption on CVD risk factors in a community-based population. Data on the effects of fruit and vegetable intake on LDL are inconsistent. Fruit and vegetable consumption decreased LDL concentration in hypercholesterolemic subjects (Suido et al., 2002). A diet rich in vegetables, fruit and cereals may provide protection against cardiovascular disease (Eastwood, 1999; Prior, 2003). Vegetables and cereals are rich sources of a variety of nutrients, including vitamins, trace minerals, dietary fiber and many other classes of biologically active compounds (Lampe, 1999). These phytochemicals can have complementary and overlapping mechanisms of action, including modulation of detoxification enzymes, stimulation of the immune system, reduction of platelet aggregation, modulation of cholesterol synthesis and hormone metabolism, reduction of blood pressure, and antioxidant sources (Gordon, 1996). In recent years, many studies have focused on the bioavailability of phenolic compounds in the prevention and treatment of hyperlipidemia and obesity. Phenolic compounds and flavonoids have pharmacological properties such as antioxidant, antimutagenic, antithrombotic, antiinflammatory, anti-cancer and hypolipidemic (Monfort et al., 1995; Son \& Lewis, 2002). They are widely distributed in plants and form part of the human diet. So we formulated two mixtures from cereals and vegetables which contain sources rich in dietary fibers and phenolic compounds. The objective of the present study was to prepare two dietary mixtures and evaluate their hypolipidemic effects in hyperlipidemic rats. The chemical compositions of the studied mixtures were also assessed. The safety of these mixtures was evaluated through the examination of liver and kidney functions.

\section{MATERIALS AND METHODS}

\subsection{Materials}

\section{Plant materials}

The plant materials used in this investigation were the parsley herb (Petoslimum crispum), cabbage head
(Brassica oleracea), green pepper (Capsicum annum), red beetroot (Beta vulgaris) and whole wheat. All plant materials were purchased from local market.

\section{Animals}

Male white albino rats of $83.8 \pm 3.375 \mathrm{~g}$ average body weight were used throughout the study. The animals were kept individually in stainless steel cages at room temperature of about $25 \pm 2^{\circ} \mathrm{C}$, food and water were supplied ad-libitum for two months.

\subsection{Methods}

\section{Preparation of plant materials}

Parsley herb, green pepper and beet root were washed with tap water and then cut into small pieces. Cabbage heads were peeled off and cut into slices. All studied plants were dried separately in an air-circulated oven at $40^{\circ} \mathrm{C}$ to complete dryness. All dried plant materials were reduced separately into powder form as far as possible and stored in plastic bags in a refrigerator at $4^{\circ} \mathrm{C}$.

\section{Preparation of mixtures}

Two mixtures were prepared from the different dried plants. Dried powder of whole wheat, cabbage, parsley and green pepper were mixed together in the ratio of $6: 2: 1: 1$, respectively for the preparation of mixture (1), while mixture (2) was made up of whole wheat, red beetroot, parsley and green pepper in the ratio of 6:2:1:1, respectively. These mixtures were used in the preparation of a control diet $(30 \%)$ for feeding hyperlipidemic rats.

\section{Chemical analysis of mixed samples}

Proximate compositions including crude protein content, crude fiber, ash and crude fat were analyzed. Crude protein content was determined by estimating the nitrogen content using the Kjedahl method. Ash content was determined by incineration at $600^{\circ} \mathrm{C}$. Crude fat was determined by the Soxlet method and the crude fibers were assayed by acid digestion and alkali digestion. Dried samples were analyzed for the above compositions in duplicate, in accordance with the AOAC standards (1995). Total dietary fiber content of the both mixtures was determined according to the method of AOAC (1997). The mineral content ( $\mathrm{K}, \mathrm{Na}, \mathrm{Fe}, \mathrm{Ca}$ and $\mathrm{Zn}$ ) was determined using an atomic absorption technique spectrophotometer (Varian spectr AA 220).

\section{Determination of total phenolic compounds}

Total phenolic compounds were extracted from the dry powder samples of the plants under study according to the method of Velioglu et al. (1998). Each sample $(200 \mathrm{mg})$ was extracted separately 
with $2 \mathrm{ml}$ of methanol $(80 \%)$ containing $1 \% \mathrm{HCl}$ at room temperature in a shaker for 2 hours and then centrifuged at $3000 \mathrm{rpm}$ for $10 \mathrm{~min}$. The upper layer was collected in different clean tubes and reextraction of the residue was carried out using the same previous procedure. The second extract was added to the first and used for the determination of total phenolic compounds. Total phenolic compounds were determined colorimetricaly in the powder mixtures using the Folin-Ciocalteu reagent (Singleton \& Rossi, 1965). Absorbance was measured at $765 \mathrm{~nm}$ using a UVPC spectrophotometer. The total phenolic content was expressed as gallic acid equivalents (GAE) in milligrams per 100 grams dry material.

\section{Determination of vitamin $E$}

Vitamin $E$ was determined according to the method of Amaral et al. (2005). Samples from each plant mixture ( 300mg) were accurately weighed in glass screw cap tubes and homogenized with $2 \mathrm{ml}$ ethanol by vortex mixing $(1 \mathrm{~min}), 100 \mu \mathrm{l}$ of butylated hydroxy toluene $(10 \mathrm{mg} / \mathrm{ml})$ was added for the protection of tocopherols from oxidation. Subsequently, $4 \mathrm{ml}$ hexane was added and again the vortex was mixed for $1 \mathrm{~min}$. After that, $2 \mathrm{ml}$ saturated $\mathrm{NaCl}$ aqueous solution were added, the mixture was homogenized (1 min), centrifuged (2 $\min , 5000 \mathrm{~g}$ ) and the clear upper layer was carefully transferred to another glass screw cap tube. The sample was re-extracted twice with hexane. The combined extracts were dried under a nitrogen stream at room temperature. The samples were transferred to microcentrifuge tubes with $1.5 \mathrm{ml}$ of hexane and finally, dehydrated with anhydrous sodium sulphate. The extract was centrifuged (10000g, 20 sec.), transferred into a dark injection vial and analyzed by HPLC. HPLC analysis was carried out using an HPLC/Agilent model, Agilent 1100 G 1311A Quat pump, G1322A Degasser, G 1329A Autosampler, G 1330A Chiller, G 1316A column compartment, fluorescence detector PC and Chemstation software along with an SI (150 $X 4.6 \mathrm{~mm}$ ) column. The wave length of excitation was at $290 \mathrm{~nm}$ and emission at $330 \mathrm{~nm}$. The mobile phase was a mixture of hexane and isopropanol $(99: 1, \mathrm{v} / \mathrm{v})$ at a flow rate of $1 \mathrm{ml} / \mathrm{min}$. The concentration of vitamin $E$ in the samples was obtained by comparing their peak areas with the peak area of standards in relation to concentration.

\section{Determination of $\beta$-carotene}

$\beta$-carotene was determined using the HPLC method as described by Scoot (2001). Ten grams from each mixture of samples were weighed in glass screw cap tubes and homogenized with 20 $\mathrm{ml}$ ethanol by vortex mixing $(5 \mathrm{~min})$, then $10 \mathrm{ml}$ of hexane was added, mixed for 2 min, centrifuged (5 min, 5000g) and the clear upper layer was carefully transferred to another glass screw cap tube. The sample was re-extracted twice with hexane. Then 7 $\mathrm{ml}$ of the hexane extracts were dried to completion under a nitrogen stream and resuspended in $1 \mathrm{ml}$ of $50 \%$ ethanol for analysis.

\section{HPLC System}

The samples were run using Waters Melinnium 3.2 software using a system equipped with a binary pump system (Waters 515), an autoinjector (Waters 717 plus), a PDA detector (Waters 996), and a column heater (SpectraPhysics SP8792). The compounds were separated on a $4.6 \times 250$ $\mathrm{mm}, 5 \mu \mathrm{m}$, YMC Carotenoid column (C-30 reversephase) purchased from Waters (Milford, MA), which was maintained at $35 \mathrm{C}$. For the analysis of $\beta$-carotene, the following gradient system was used: methanol/water/triethylamine (90:10:0.1v/v/v) (A), and methanol/MTBE/triethylamine $(6: 90: 0.1 \mathrm{v} / \mathrm{v} / \mathrm{v})$ (B); gradient (min/\%A) 0/99, 8/99, 45/0, 50/0, and $53 / 99$. The column was brought back to initial conditions and allowed to equilibrate for 10 minutes before injection. All solvents were filtered and degassed before use. $\beta$-carotene was analyzed at $450 \mathrm{~nm}$.

\section{Preparation of diets}

Experimental diets were prepared as in Table (1). The control diet contained $10 \%$ fat from corn oil, $10 \%$ protein from casein, 3\% fiber from cellulose. The hypercholesterolemic diet contained $25 \%$ fat from butter as a source of highly saturated fat, $10 \%$ protein from casein, $1 \%$ cholesterol, $0.25 \%$ cholic acid. The control diets containing mixture (1) or (2) contained $10 \%$ protein from plant protein in the mixtures used and casein, 10\% fat from corn oil and the fat determined in the mixtures. A salt mixture and vitamin mixtures were prepared according to Briggs \& Williams (1963) and Morcos (1967), respectively and added to all diets prepared in the study as $3.5 \%$ and $1 \%$ respectively. Oil soluble vitamins were given orally in a dose of $0.1 \mathrm{ml} / \mathrm{rat}$ per week. The hyperlipidemic diet was prepared according to Zulet et al. (1999) but with a modification by adding butter fat instead of coconut oil as a source of saturated fat.

\section{Design of experimental study}

Thirty rats were assigned to two dietary groups. The first group (6 rats) received a control diet (CC), while twenty-four rats (the second groups) were fed a hyperlipidemic diet $(\mathrm{HH})$. This first stage continued for a month. After the development of hyperlipidemia, the hyperlipidemic rats were divided into four sub-groups of six rats each (second stage). The rats in the first sub-group continued on the same hyperlipidemic diet ( $\mathrm{HH}$ group), the second sub-group (HC group) of rats received the control diet. The remaining two hyperlipidemic subgroups of rats received the control diet containing 
$30 \%$ of mixture 1 (HM1 group) or mixture 2 (HM2 group) for four weeks (diet compositions shown in Table 1). During this experimental period the control group continued on the same control diet (CC group). During the experiment, body weight and food intake were recorded weekly. At the end of the first and second stages, total food intake, body weight gain and feed efficiency ratio were calculated. Blood samples were collected from all rats after an overnight fast at the end of the first and second stages for the determination of plasma total lipid (Toro \& Ackerman, 1975), total cholesterol (T-Ch) (Watson, 1960), high-density lipoprotein cholesterol (HDL-Ch) (Burstein et al., 1980), lowdensity lipoprotein cholesterol (LDL-Ch) (Gerard \& Gerald, 1981) and triglycerides (TG) (Megraw et al., 1979). T-Ch / HDL- Ch ratio was calculated. The nutritional safety of the plant mixtures was studied through the evaluation of liver and kidney functions. The plasma levels of creatinine (Houot, 1985) and urea (Fawcett \& Scott, 1960) were determined as indicators of kidney function, while the activity of aspartate transaminase (AST) and alanine transaminase (ALT) (Reitman \& Frankel, 1957) were determined as indicators of liver function.

\section{Statistical analysis}

Values were expressed as mean \pm SE. Data from the first stage were analyzed statistically using the student's t-test. Data from the second stage were analyzed statistically using the one-way analysis of variance ANOVA followed by Duncan's test (Duncan, 1955). In all cases, $p<0.05$ was used as the criterion of statistical significance.

\section{RESULTS}

The chemical compositions of the mixtures shown in Table (2) clarified that both mixtures

Table 1

Composition of different experimental diets $(\mathrm{g} / 100 \mathrm{~g})$

\begin{tabular}{|c|c|c|c|c|}
\hline \multirow[t]{2}{*}{ Ingredients } & \multicolumn{4}{|c|}{ Diets } \\
\hline & Control & Hypercholesterolemic & Mixture 1 & Mixture 2 \\
\hline Casein & $11.9^{*}$ & 11.9 & 8.33 & 8.33 \\
\hline Corn oil & 10 & - & 9.66 & 9.43 \\
\hline Butter & - & 25 & - & - \\
\hline Sucrose & 23.5 & 38.2 & 22.9 & 22.9 \\
\hline Starch & 47.1 & 19.15 & 35.86 & 29.23 \\
\hline Salt mix. & 3.5 & 3.5 & 3.5 & 3.5 \\
\hline Vit. mix. & 1 & 1 & 1 & 1 \\
\hline Fiber & 3 & - & 3 & 3 \\
\hline Cholesterol & - & 1 & - & - \\
\hline Cholic acid & - & 0.25 & - & - \\
\hline Powder (mix. 1) & - & - & 15.75 & - \\
\hline Powder (mix. 2) & - & - & - & 22.61 \\
\hline
\end{tabular}

Table 2

Chemical composition of mixtures (1) and (2)

\begin{tabular}{lcc}
\hline \multicolumn{1}{c}{ Ingredients/ 100g dry samples } & Mixture $\mathbf{1}$ & Mixture 2 \\
\hline Fat $(\mathrm{g})$ & 2.1 & 2.5 \\
Protein $(\mathrm{g})$ & 19.1 & 13.3 \\
Ash $(\mathrm{g})$ & 7.4 & 5.5 \\
Crude fibers $(\mathrm{g})_{\text {Carbohydrate }^{*}(\mathrm{~g})}$ & 1.8 & 1.2 \\
Total dietary fiber $(\mathrm{g})$ & 69.6 & 77.5 \\
$\mathrm{~K}(\mathrm{mg})$ & 18.3 & 16.8 \\
$\mathrm{Na}(\mathrm{mg})$ & 1250.1 & 1319.4 \\
$\mathrm{Zn}(\mathrm{mg})$ & 107.1 & 144.5 \\
Fe $(\mathrm{mg})$ & 3.0 & 2.8 \\
$\mathrm{Ca}(\mathrm{mg})$ & 9.0 & 9.0 \\
Total phenolic compounds (mg GAE) & 214.4 & 165.3 \\
Vitamin E $(\mathrm{mg})$ & 1910 & 1710 \\
$\beta$-carotene $(\mu \mathrm{g})$ & 7.4 & 4.5 \\
\hline
\end{tabular}

${ }^{*}$ Carbohydrate is defined as the residue excluding protein, lipid, crude fiber and ash (= 100 - proteins - lipid - crude fiber - ash). GAE: Gallic acid equivale 
contain high percentages of protein (19.1 and 13.3 respectively). It can also be seen that fat content was $2.1 \%$ and $2.5 \%$. Carbohydrate contents were $69.6 \%$ and $77.5 \%$ in mixtures (1) and (2) respectively. Crude fibers were present in mixture (1) and (2) as $1.8 \%$ and $1.2 \%$ respectively. The ash contents were 7.4 and $5.5 / 100 \mathrm{~g}$ in sample mixtures (1) and (2) respectively. Total dietary fibers present in mixtures (1) and (2) were $18.3 \%$ and $16.8 \%$ respectively. Vitamin $\mathrm{E}$ represented 7.4 and 4.5 $\mathrm{mg}$ respectively. $\beta$-carotene contents in mixtures (1) and (2) were 830 and $786 \mu \mathrm{g}$ respectively. K, $\mathrm{Na}, \mathrm{Zn}, \mathrm{Fe}$ and $\mathrm{Ca}$ were present in mixture (1) at 1250.1, 107.1, 3.0, 9.0 and $214.4 \mathrm{mg}$ respectively; while they were present in mixture (2) at 1319.4, $144.5,2.8,9.0$ and $165.3 \mathrm{mg}$ respectively. Total phenolic compounds were present in mixture (1) and (2) at 1910 and $1710 \mathrm{mg}$ gallic acid equivalents respectively.

The nutritional parameters of normal and hyperlipidemic rats from the first stage are shown in Table (3). The results revealed that non-significant changes were found in all nutritional parameters between normal and hyperlipidemic rats.
The plasma lipid profiles of hyperlipidemic rats (first stage) are shown in Table (4). Rats fed the hyperlipidemic diet showed a significant increase in the plasma levels of total lipids $(+152 \%, p<0.001)$, T-Ch (+131\%, p <0.001), TG (+9\%, p <0.001) T-Ch/HDL-Ch ratio $(+260 \%, p<0.001)$ and LDLCh $(+80 \%$, p < 0.001), which was accompanied by a decrease in HDL-Ch $(-35 \%, p<0.001)$ when compared to normal rats.

The nutritional parameters of hyperlipidemic rats after feeding different dietary treatments are shown in Table (5). No significant changes were observed in all nutritional parameters of rats subjected to different dietary treatments. Hyperlipidemic rats fed the control diet containing mixture (1) or (2) showed a non-significant reduction in final body weight and body weight gain when compared with different groups.

Table (6) shows the plasma lipid profile of different experimental groups in the second stage. The replacement of the hyperlipidemic diet with the control diet and or control diet containing mixture (1) or (2) for four weeks showed a significant reduction in the plasma lipid profile in all rat groups with different

Table 3

Nutritional parameters of normal and Hyperlipidemic rats (first stage)

\begin{tabular}{lcc}
\hline \multicolumn{1}{c}{ Parameters } & $\begin{array}{c}\text { CC } \\
\text { (Mean } \pm \text { SE) }\end{array}$ & $\begin{array}{c}\text { HH } \\
\text { (Mean } \pm \text { SE) }\end{array}$ \\
\hline Initial B. W. (g) & $83.8 \pm 4.376$ & $83.8 \pm 2.374$ \\
Final B. W. (g) & $176 \pm 9.123$ & $164.2 \pm 5.452$ \\
B. W. gain (g) & $92.2 \pm 6.288$ & $80.4 \pm 3.721$ \\
Total Food Intake (g) & $449.5 \pm 26.901$ & $426.1 \pm 14.583$ \\
Feed Efficiency Ratio & $0.206 \pm 0.009$ & $0.189 \pm 0.006$ \\
\hline
\end{tabular}

CC: Normal group fed the control diet. HH: Hypercholesterolemic rats fed the hypercholesterolemic diet.

Table 4

Plasma lipid profile of normal and Hyperlipidemic rats (first stage)

\begin{tabular}{lcc}
\hline \multicolumn{1}{c}{ Parameters } & $\begin{array}{c}\text { CC } \\
\text { (Mean } \pm \text { SE) }\end{array}$ & $\begin{array}{c}\text { HH } \\
\text { (Mean } \pm \text { SE) }\end{array}$ \\
\hline Total lipids $(\mathrm{mg} / \mathrm{dl})$ & $341.3 \pm 16.632$ & $859^{*} \pm 9.769$ \\
$\%$ Change & - & 152 \\
T-Ch $(\mathrm{mg} / \mathrm{dl})$ & $86.7 \pm 2.903$ & $200.3^{*} \pm 3.267$ \\
$\%$ Change & - & 131 \\
TG $(\mathrm{mg} / \mathrm{dl})$ & $80 \pm 1.391$ & $87.5^{*} \pm 0.748$ \\
$\%$ Change & - & 9 \\
LDL-Ch (mg/dl) & $21.4 \pm 0.628$ & $105.2^{*} \pm 3.036$ \\
$\%$ Change & - & 80 \\
HDL-Ch (mg/dl) & $43.4 \pm 0.711$ & $28.2^{*} \pm 0.518$ \\
$\% C h a n g e$ & - & -35 \\
T-Ch/HDL ratio & $2 \pm 0.0802$ & $7.2^{*} \pm 0.209$ \\
$\% C h a n g e$ & - & 260 \\
\hline
\end{tabular}

Values significantly differ from normal rats: * $p<0.0$. CC: Normal group fed the control diet. $\mathrm{HH}$ : Hypercholesterolemic rats fed on hypercholesterolemic diet. T-Ch: total cholesterol, TG: triglycerides, LDL-Ch: low density lipoprotein-cholesterol. HDL-Ch: high density lipoprotein-cholesterol. 
Table 5

Nutritional parameters of different experimental groups (Mean \pm SE)

\begin{tabular}{lccccc}
\hline Groups & $\begin{array}{c}\text { Initial body } \\
\text { weight } \\
\mathbf{( g )}\end{array}$ & $\begin{array}{c}\text { Final body } \\
\text { weight } \\
\mathbf{( g )}\end{array}$ & $\begin{array}{c}\text { Body weight } \\
\text { gain } \\
\mathbf{( g )}\end{array}$ & $\begin{array}{c}\text { Total Food } \\
\text { intake } \\
\mathbf{( g )}\end{array}$ & $\begin{array}{c}\text { Feed } \\
\text { efficiency } \\
\text { ratio }\end{array}$ \\
\hline $\mathrm{CC}$ & $176 \pm 9.12 \mathrm{a}$ & $262.3 \pm 11.35 \mathrm{a}$ & $86.33 \pm 5.92 \mathrm{a}$ & $430 \pm 15.42 \mathrm{a}$ & $0.20 \pm 0.01 \mathrm{a}$ \\
$\mathrm{HH}$ & $164.8 \pm 9.82 \mathrm{a}$ & $246.2 \pm 8.13 \mathrm{a}$ & $81.33 \pm 2.23 \mathrm{a}$ & $407.7 \pm 25.54 \mathrm{a}$ & $0.20 \pm 0.01 \mathrm{a}$ \\
$\mathrm{HB}$ & $172 \pm 12.12 \mathrm{a}$ & $253.3 \pm 12.02 \mathrm{a}$ & $81.33 \pm 2.53 \mathrm{a}$ & $415.2 \pm 17.47 \mathrm{a}$ & $0.20 \pm 0.01 \mathrm{a}$ \\
$\mathrm{HM} 1$ & $166.33 \pm 12.88 \mathrm{a}$ & $241.5 \pm 9.60 \mathrm{a}$ & $75.17 \pm 4.41 \mathrm{a}$ & $449.5 \pm 17.25 \mathrm{a}$ & $0.17 \pm 0.01 \mathrm{a}$ \\
$\mathrm{HM} 2$ & $153.67 \pm 14.74 \mathrm{a}$ & $233.5 \pm 14.41 \mathrm{a}$ & $79.83 \pm 3.66 \mathrm{a}$ & $427.2 \pm 19.66 \mathrm{a}$ & $0.19 \pm 0.01 \mathrm{a}$ \\
\hline
\end{tabular}

In each row same letters mean non significant difference; different letter mean the significance among the tested groups at 0.05 probability. CC: Normal group fed the control diet. HH: Hypercholesterolemic rats fed the hypercholesterolemic diet.

HC: Hypercholesterolemic rats fed the control diet. HM1: Hypercholesterolemic rats fed the control diet containing $30 \%$ mixture 1. HM2: Hypercholesterolemic rats fed the control diet containing $30 \%$ mixture.

Table 6

Plasma lipid profile of different experimental groups (Mean \pm SE)

\begin{tabular}{|c|c|c|c|c|c|c|c|c|c|c|c|}
\hline \multirow{2}{*}{\multicolumn{2}{|c|}{ Parameters }} & \multicolumn{10}{|c|}{ Groups } \\
\hline & & \multicolumn{2}{|c|}{$\mathrm{CC}$} & \multicolumn{2}{|c|}{$\mathrm{HH}$} & \multicolumn{2}{|c|}{$\mathrm{HC}$} & \multicolumn{2}{|c|}{ HM1 } & \multicolumn{2}{|c|}{ HM2 } \\
\hline & & B & A & B & A & B & A & B & A & B & A \\
\hline \multirow{3}{*}{$\begin{array}{l}\text { Total } \\
\text { lipids } \\
\text { (mg/dl) }\end{array}$} & Mean & 341.33 & $351.99^{\mathrm{a}}$ & 914.6 & $941.34^{c}$ & 853.80 & $717.14^{b}$ & 820.79 & $687.42^{b}$ & 846.79 & $697.59^{b}$ \\
\hline & \pm SE & 16.63 & 15.56 & 21.79 & 19.52 & 12.53 & 17.29 & 14.49 & 17.62 & 18.34 & 27.36 \\
\hline & $\%$ Change & - & - & - & 3 & - & -16 & - & -16 & - & -18 \\
\hline \multirow{3}{*}{$\begin{array}{l}\text { T-Ch } \\
(\mathrm{mg} / \mathrm{dl})\end{array}$} & Mean & 86.73 & $89.06^{a}$ & 200.67 & $213.90^{c}$ & 200.08 & $154.31^{b}$ & 200.33 & $142.8^{b}$ & 200.25 & $147.62^{b}$ \\
\hline & $\pm \mathrm{SE}$ & 2.90 & 2.73 & 8.64 & 10.04 & 5.35 & 6.90 & 10.28 & 7.413 & 5.35 & 8.15 \\
\hline & $\%$ Change & - & - & - & 7 & - & -23 & - & -29 & - & -26 \\
\hline \multirow{3}{*}{$\begin{array}{l}\text { HDL- } \\
\text { Ch } \\
(\mathrm{mg} / \mathrm{dl})\end{array}$} & Mean & 43.37 & $42.87^{c}$ & 29.11 & $28.15^{\mathrm{a}}$ & 27.27 & $35.95^{b}$ & 28.18 & $39.0^{\mathrm{b}}$ & 28.38 & $37.82^{b}$ \\
\hline & \pm SE & 0.71 & 0.81 & 0.83 & 0.60 & 1.32 & 0.92 & 1.47 & 0.668 & 1.02 & 0.76 \\
\hline & $\%$ Change & - & - & - & -3 & - & 32 & - & 38 & - & 33 \\
\hline \multirow{3}{*}{$\begin{array}{c}\mathrm{T}-\mathrm{Ch} / \\
\mathrm{HDL}- \\
\text { Ch ratio }\end{array}$} & Mean & 2.00 & $2.08^{a}$ & 6.94 & $7.61^{\mathrm{c}}$ & 7.47 & $4.32^{b}$ & 7.20 & $3.54^{\mathrm{b}}$ & 7.12 & $3.93^{b}$ \\
\hline & $\pm \mathrm{SE}$ & 0.08 & 0.08 & 0.43 & 0.37 & 0.58 & 0.28 & 0.51 & 0.236 & 0.40 & 0.29 \\
\hline & $\%$ Change & - & - & - & 10 & - & -42 & - & -51 & - & -45 \\
\hline \multirow{3}{*}{$\begin{array}{l}\text { LDL-Ch } \\
(\mathrm{mg} / \mathrm{dl})\end{array}$} & Mean & 21.35 & $22.02^{\mathrm{a}}$ & 111.99 & $123.50^{c}$ & 107.88 & $92.22^{b c}$ & 98.51 & $80.40^{b}$ & 102.32 & $81.28^{b}$ \\
\hline & \pm SE & 0.63 & 0.46 & 10.31 & 11.76 & 5.28 & 4.24 & 3.44 & 1.97 & 6.15 & 2.927 \\
\hline & $\%$ Change & - & - & - & 10 & - & -15 & - & -18 & - & -21 \\
\hline \multirow{3}{*}{$\begin{array}{c}\mathrm{TG} \\
(\mathrm{mg} / \mathrm{dl})\end{array}$} & Mean & 80.02 & $82.86^{a}$ & 84.98 & $88.17^{a b}$ & 87.8 & $87.91^{a b}$ & 89.52 & $82.20^{a}$ & 87.84 & $82.73^{\mathrm{a}}$ \\
\hline & $\pm \mathrm{SE}$ & 1.39 & 1.11 & 1.27 & 1.42 & 2.21 & 2.46 & 1.28 & 2.25 & 1.49 & 1.97 \\
\hline & $\%$ Change & - & - & - & 4 & - & - & - & -8 & - & -6 \\
\hline
\end{tabular}

In each row same letters mean non significant difference; different letter means the significance among the tested groups at 0.05 probability. CC: Normal group fed the control diet. HH: Hypercholesterolemic rats fed the hypercholesterolemic diet.

HC: Hypercholesterolemic rats fed the control diet. HM1: Hypercholesterolemic rats fed the control diet containing $30 \%$ mixture 1. HM2: Hypercholesterolemic rats fed the control diet containing 30\% mixture 2. T-Ch: total cholesterol, TG: triglycerides,

LDL-Ch: low density lipoprotein-cholesterol, HDL-Ch: high density lipoprotein-cholesterol.

degrees when compared with hyperlipidemic rats still fed the hyperlipidemic diet. The hyperlipidemic rats fed the control diet (HB group) showed a significant reduction in plasma levels of total lipids, T-Ch, LDLCh and T-Ch/HDL-Ch ratio (-15\%, $-23 \%,-15 \%,-42 \%$ respectively). While HDL-Ch increased significantly $(+32 \%)$ in comparison with hyperlipidemic rats fed the hyperlipidemic diet $(\mathrm{HH})$.

Hyperlipidemic rats fed the control diet containing mixture (1) or (2) showed a significant 
improvement in plasma lipid profile with different degrees when compared with hyperlipidemic rats fed the hyperlipidemic diet. The plasma level of LDL-Ch and TG reduced significantly in hyperlipidemic rats fed the control diet containing mixture (1) or (2) when compared with different groups.

The plasma levels of creatinine and urea as indicators of kidney function showed non-significant changes in all groups (Table 7). In addition, the plasma levels of AST and ALT as indicators of liver function showed non-significant changes in all studied groups. This revealed the complete safety of the mixtures studied.

\section{DISCUSSION}

Hyperlipidemia was induced in rats by feeding a diet rich in saturated fat (25\%). The assessment of the lipid profile in the plasma of rats fed a high-fat diet enriched in saturated fat and cholesterol revealed a situation of hyperlipidemia which was accompanied by a decrease in HDL-Ch and an increase in LDLCh. These alterations resembled a situation of type II hyperlipidemia in humans (Tholstrup et al., 1995), which could be associated with a down- regulation in LDL receptors by the cholesterol and saturated fatty acids included in the diet (Stucchi et al., 1995).

Cholesterol is an animal sterol best known for its association with atherosclerosis and coronary heart disease. High levels of LDL cholesterol are deposited in the interior of blood vessels resulting in hardened arteries, narrowing of the blood vessels and coronary heart disease. High levels of HDL cholesterol have been shown to reduce some of the harmful effects of LDL cholesterol. HDL picks up and transports cholesterol in the blood back to the liver, which leads to its elimination from the body. HDL can help to keep LDL cholesterol from building up in the walls of the arteries (Awan, 1993).

In the present study two dietary mixtures from whole cereals and vegetables were prepared and the hypolipidemic effect on hyperlipidemic rats was evaluated.

In the present study, a significant improvement in the plasma lipid profile and a non-significant reduction in body weight gain and final body weight in hyperlipidemic rats fed the control diet containing $30 \%$ of mixture (1) or (2) were shown, which may be attributed to the presence of phenolic compounds, plant proteins, glucosinolates, betalains, carotenoids and dietary fibers. All these compounds are present in both mixtures studied, as shown in table (2).

In the present study, cabbage and red beetroot were used in the preparation of mixtures (1) and (2) respectively. Cabbage and beetroot contain two major types of phytochemicals, glucosinolates (GLS) and betalains respectively, which were previously known to possess antioxidant activity (Fahey et al., 2001; Zielinska-Przyjmska et al., 2009). Therefore, we decided to evaluate their hypolipidemic effect.

Cabbage is a good source of phytochemicals and has high antioxidant activity (Cao et al., 1996). Cabbage belongs to the Brassicaceae family, Crucifers, and contains many bioactive components including flavonoids (e.g. quercetin), minerals (e.g. selenium) and vitamins (e.g. Vitamin C) (Finley et al., 2001; Jeffery et al., 2003). Among the moststudied bioactive compounds in crucifers associated with cancer protection are glucosinolates (Zareba \& Serradelf, 2004). GLS share a similar basic structure consisting of a $\beta$-d-thioglucose group. GLSs are not bioactive in the animal that consumes them until they have been enzymatically hydrolyzed to an associated isothiocyanate (Rouzaud et al., 2003) by the endogenous myrosinase enzyme that is released by disruption of the plant cell through harvesting, processing, or mastication (Finley, 2005). In vitro and in vivo studies have reported that isothiocyanates affect many phases of cancer development, including the modulation of phases I and II detoxification enzymes. They function as a direct antioxidant or as an indirect antioxidant by phase II enzyme induction, modulating cell signaling, induction of apoptosis, control of the cell cycle, and reduction of Helicobacter infections. The most characterized GLS compounds are sulphoraphane, phenethyl isothiocyanate, allyl isothiocyanate and indole-3carbinol, but many other isothiocyanates that are present in lower quantities may also contribute to the anti-carcinogenic properties of crucifers (Fahey et al., 2001; 2002). Sulforaphane, indole-3carbinol, glucaric acid, and other isothiocyanates

Table 7

Liver and kidney function of different experimental groups (Mean $\pm \mathrm{SE}$ )

\begin{tabular}{lcccc}
\hline Groups & $\begin{array}{c}\text { Creatinine } \\
(\mathbf{m g} / \mathbf{d l})\end{array}$ & $\begin{array}{c}\text { Urea } \\
(\mathbf{m g} / \mathbf{d l})\end{array}$ & $\begin{array}{c}\text { ALT } \\
(\text { IU/l) }\end{array}$ & $\begin{array}{c}\text { AST } \\
(\text { IU/l) }\end{array}$ \\
\hline $\mathrm{CC}$ & $0.59 \mathrm{a} \pm 0.01$ & $25.40 \mathrm{a} \pm 0.69$ & $57.17 \mathrm{a} \pm 1.97$ & $136.00 \mathrm{a} \pm 1.39$ \\
$\mathrm{HH}$ & $059 \mathrm{a} \pm 0.01$ & $25.83 \mathrm{a} \pm 0.98$ & $58.00 \mathrm{a} \pm 1.48$ & $136.33 \mathrm{a} \pm 2.08$ \\
$\mathrm{HC}$ & $0.58 \mathrm{a} \pm 0.01$ & $25.37 \mathrm{a} \pm 0.59$ & $56.33 \mathrm{a} \pm 0.80$ & $136.83 \mathrm{a} \pm 0.79$ \\
$\mathrm{HM} 1$ & $0.59 \mathrm{a} \pm 0.01$ & $25.20 \mathrm{a} \pm 0.61$ & $56.00 \mathrm{a} \pm 0.58$ & $136.83 \mathrm{a} \pm 1.08$ \\
$\mathrm{HM} 2$ & $0.58 \mathrm{a} \pm 0.01$ & $25.87 \mathrm{a} \pm 0.79$ & $56.50 \mathrm{a} \pm 0.43$ & $136.67 \mathrm{a} \pm 0.88$ \\
\hline
\end{tabular}

In each row same letters mean non significant difference; different letter mean the significance among the tested groups at 0.05 probability. $\mathrm{CC}$ : Normal group fed the control diet. $\mathrm{HH}$ : Hypercholesterolemic rats fed the hypercholesterolemic diet. HC: Hypercholesterolemic rats fed the control diet. HM1: Hypercholesterolemic rats fed the control diet containing 30\% mixture 1. HM2: Hypercholesterolemic rats fed the control diet containing $30 \%$ mixture 2 . ALT: alanine transaminase, AST: aspartate transaminase. 
are antioxidants and potent stimulators of natural detoxifying enzymes in the body. These compounds are believed to be responsible for the lowered risk of atherosclerosis and cancer (Hecht, 1999).

Beetroot contains red pigments (betacyanins) and yellow pigments (betaxanthins), known collectively as betalains. Medicinally, beetroot is employed as a popular folk remedy to stimulate the immune system and for the treatment of liver and kidney diseases. It is also employed as a special diet in the treatment of cancer (Chevallier, 1996). Betalains have been proven to be a potent cancer chemopreventive agent in-vivo (Kapadia et al., 1996). Beetroot products inhibited neutrophil oxidative metabolism in a concentration-dependent manner. Also beetroot showed pro-apoptotic effects at a concentration range of $0.1-10 \%$ in a $24 \mathrm{~h}$ culture of stimulated neutrophils. So beetroot have antioxidant and antiinflammatory capacity (Zielinska-Przyjmska et al., 2009). Based on this strong antioxidant activity of cabbage and beetroot and the fact that they are already being used as food, we used them in the preparation of mixtures (1) and (2) and evaluated their hypolipidemic effect in hyperlipidemic rats.

Whole wheat was used in the preparation of both mixtures as a cereal source. Whole wheat is a good source of dietary fiber, B vitamins and minerals and possesses antioxidant activity (Slavin et al., 2001). Epidemiological studies have clearly demonstrated that a diet containing whole-grain cereals can protect against metabolic disorders such as cardiovascular diseases (Anderson, 2003) and diabetes (Venn \& Mann, 2004). The effect is mainly attributed to the fiber and micronutrients in the outer layer of the grain and in the germ fraction (Slavin et al., 1999; Thompson, 1994). The protective effects of cereal fibers depend on their solubility. Soluble fiber (soluble arabinoxylans and $\beta$-glucans) can lower blood cholesterol (Braaten et al., 1994; Olmo et al., 2007) and reduce the post-prandial glycaemic response (Casiraghi et al., 2006). The mechanism of the dietary fiber cholesterol lowering effect could be the ability of fiber to increase bile acid loss (Jenkins et al., 2000). The physicochemical properties of soluble fiber in the intestinal lumen have a very significant repercussion on hepatic cholesterol metabolism and on the synthesis by processing them in the intravascular compartment and the catabolism of lipoproteins. The main outcome of fiber action is a lowering of hepatic cholesterol pools as a result of cholesterol being diverted to bile acid synthesis, and less cholesterol delivery to the liver through chylomicron remnants (Fernandez, 2001). Also dietary fiber reduces plasma triglyceride levels by delaying its absorption from the small intestine (Galisteo et al., 2008). The hypotriglyceridemic effect of soluble dietary fiber results from the inhibition of hepatic lipogenesis through the modulation of fatty acid synthase activity (Kok et al., 1996). The nonsignificant reduction in final body weight and body weight gain in hyperlipidemic rats fed the control diet containing $30 \%$ of mixture (1) or (2) may be attributed to the presence of dietary fiber. The main hypothesis explaining these reductions in final body weight and body weight gain is the strong feeling of satiety provided by dietary fiber as reported by Pereira \& Ludwig (2001).

Our prepared mixtures contain $19.1 \%$ and $13.3 \%$ protein in mixtures (1) and (2) respectively. Plant proteins have been previously shown to have hypocholesterolemic activity (Atwal et al., 1997). Plant protein showed a remarkable cholesterol lowering effect in pigs fed a cholesterol-rich diet, compared with casein (Martins et al., 2005).

Mixtures (1) and (2) contain 830 and $786 \mu \mathrm{g}$ $\beta$-carotene $/ 100 \mathrm{~g}$ sample. It was reported previously that $\beta$-carotene reduces cholesterol in-vitro and invivo (Fuhrman et al., 1997; Elson et al., 1999).

Whole-grain cereals and vegetables are a major source of phenolic compounds, especially phenolic acids such as ferulic, vanillic, caffeic, syringic, sinapic and p-coumaric acids (Sosulski et al., 1982). All of them have potentially antioxidant properties due to the presence of an aromatic phenolic ring that can stabilize and delocalize the unpaired electron within its aromatic ring (RiceEvans et al., 1997). Ferulic, vanillic and p-coumaric acids are the most abundant free phenolic acids in wheat. Ferulic acid is generally the predominant phenolic acid (Zhou et al., 2005; Liyana-Pathirana \& Shahidi, 2007). Phenolic compounds have been reported to reduce hepatic cholesterol concentrations and increase fecal sterol excretion in rats with hypercholesterolemia (Kotani et al., 2000; Park et al., 2002).

\section{CONCLUSIONS}

Hyperlipidemic rats fed a control diet containing mixture (1) or (2) showed significant improvements in plasma lipid profile that are of beneficial effects towards cardiovascular diseases. This improvement may be attributed to the presence of dietary fibers, glucosinolates, betalains, plant proteins, carotenoids and phenolic compounds in these mixtures. Both glucosinolates and betalains in mixtures one and two respectively showed similar activity towards hyperlipidemia. So vegetable and cereal mixtures with different ratios can be used to treat hyperlipidemia or reduce the risk of atherosclerosis.

\section{REFERENCES}

Amaral JS, Casal S, Torres D, Seabra RM, Oliveira BP. 2005. Simultaneous determination of tocopherols and tocotrienols in hazelnuts by a normal phase liquid chromatographic method. Analytical Sciences 21, 1545-1548.

Anderson JW. 2003. Whole grains protect against atherosclerotic cardiovascular disease. The Proceedings of the Nutrition Society 62, 135-142.

AOAC. 1995. Official Methods of Analysis (15th ed.). (Association of Official Analytical Chemists, Gaithersburg, MD). 
AOAC. 1997. Official methods of analysis of the Association of Official Agriculture Chemists $16^{\text {th }}$ ed. Volume II, Section 45.4.07, Methods 985.29.

Atwal AS, Kubow C, Wolynetz MS. 1997. Effect of protein source and amino acid supplementation on plasma cholesterol in guinea pig. Int. J. Vitam. Nutr. Res. 67, 192-198.

Awan JA. 1993. Elements of food and nutrition. Uni-Tech Communication, Faisalabad, Pakistan, pp. 42-44.

Braaten JT, Wood PJ, Scott FW, Wolynetz MS, Lowe MK, Bradley- White P, Collins MW. 1994. Oat betaglucan reduces blood cholesterol concentration in hypercholesterolemic subjects. Eur. J. of Clin. Nutr. 48, 465-474.

Briggs GM, Williams M.A. 1963. A new mineral mixture for experimental rat diets and evaluation of other mineral mixtures. Fed. Proc. 22, $261-266$.

Burstein M, Scholnick HR, Morfin R. 1980. Rapid method for the isolation of lipoproteins from human serum by precipitation with polyanions. Scand. J. Clin. Lab. Invest. 40, 583-595.

Cao G, Sofic E, Prior RL. 1996. Antioxidant capacity of tea and common vegetables. Journal of Agricultural and Food Chemistry 44, 3426-3431.

Casiraghi MC, Garsetti M, Testolin G, Brighenti F. 2006. Post-prandial responses to cereal products enriched with barley beta-glucan. J. of the Am. Col. of Nutr. 25, 313-320.

Chevallier A. 1996. The encyclopedia of medicinal plants. New York: DK Publishing Inc. p. 176.

Deng R. 2009. Food and food supplements with hypocholesterolemic effects. Recent patents on Food, Nutrition and Agriculture 1, 15-24.

Duncan DB. (1955). Multiple Range and Multiple F tests. Biometrics, 11: 1-42.

Eastwood MA. 1999. Interaction of dietary antioxidants in vivo: how fruit and vegetables prevent disease? QJM dan. Inter. J. of Med. 92, 527-530.

Elson CE, Peffley DM, Hentosh P, Mo H. 1999. Isoprenoid-mediated inhibition of mevalonate synthesis: potential application to cancer. Proc. Soc. Exp. Biol. Med. 22, 294-310.

Fahey JW, Zalcmann AT, Talalay P. 2001. The chemical diversity and distribution of glucosinolates and isothiocyanates among plants. Phytochemistry 56, 5-51.

Fahey JW, Zalcmann AT, Talalay P. 2002. Corrigendum to "The chemical diversity and distribution of glucosinolates and isothiocyanates among plants". Phytochemistry 59, 237.

Finley JW. 2005. Proposed criteria for assessing the efficacy of cancer reduction by plant foods enriched in carotenoids, glucosinolates, polyphenols and selenocompounds. Ann. Bot. 95, 1075-1096.

Finley JW, Ip C, Lisk DJ, Davis CD, Hintze KJ, Whanger PD. 2001. Cancer-protective properties of highselenium broccoli. J. Agric. Food Chem. 49, 26792683.

Fawcett JK, Scott JE. 1960. A rapid and precise method for the determination of urea. J. Clin. Pathol. 13: 156159.

Fernandez ML. 2001. Soluble fiber and nondigestible carbohydrate effects on plasma lipids and cardiovascular risk. Curr. Opin Lipidol. 12, 35-40.

Fuhrman B, Elis A, Aviram M. 1997. Hypocholesterolemic effect of lycopene and $\beta$-carotene is related to suppression of cholesterol synthesis and augmentation of LDL receptor activity in macrophages. Biochem. Biophys Res. Commun. 233, 658-662.
Galisteo M, Duarte J, Zarzuelo A. 2008. Effects of dietary fibers on disturbances clustered in the metabolic syndrome. J. Nutritional Biochem. 19, 71-84.

Gerard T, Gerald AL. 1981. Process and reagents for the selective separation of low density lipoprotein (LDL) and for the quantification of their components. Eur. Path. (Appl.) E.P. 76, 211-223.

Gordon MH. 1996. Dietary antioxidants in disease prevention. Nat. Prod. Rep. 13, 265-73.

Harrison D, Kathy KG, Hornig B, Drexler H. 2003. Role of oxidative stress in atherosclerosis. Am. J. Card. 91, $7 \mathrm{~A}-11 \mathrm{~A}$

Hecht SS. 1999. Chemoprevention of cancer by isothiocyanates, modifiers of carcinogen metabolism. J. Nutr. 129, 768S-74S.

Houot O. 1985. Interpretation of clinical laboratory tests. Edit. Siest G., Henny J., Schiele F., Young D. S. Biomedical publications.

Jeffery EH, Brown AF, Kurililch AC, Keck AS, Matusheski $\mathrm{N}$, Klein BP, Juvik JA. 2003. Variation in content of bioactive components in broccoli. J. Food Compos. Anal. 16, 323-330.

Jenkins DJA, Kendall CWC, Vuksan V. 2000. Viscous fibers, health claims, and strategies to reduce cardiovascular disease risk. Am. J. Clin. Nutr. 71, 401-2.

Kapadia GJ, Tokuda H, Kinoshima T, Nishino H. 1996 Chemoprevention of lung and skin cancer by Beta vulgaris (Beet) root extract. Cancer Lett. 100, 211-4.

Kok N, Roberfroid M, Delzenne N. 1996. Dietary oligofructose modifies the impact of fructose on hepatic triacylglycerol metabolism. Metabolism 45, 1547-50.

Kotani M, Matsumoto M, Fujita A, Higa S, Wang W, Suemura M, Kishimoto T, Tanaka T. 2000. Persimmon leaf extract and astragalin inhibit development of dermatitis and $\lg \mathrm{E}$ elevation in NC/ Nga mice. J. Allergy Clin. Immunol. 106, 159-166.

Lampe WJ. (1999. Health effects of vegetables and fruit: assessing mechanisms of action in human experimental studies. Am. J. Clin. Nutr. 70 (suppl), 475S-90S

Liyana-Pathirana CM, Shahidi F. 2007. The antioxidant potential of milling fractions from breadwheat and durum. Journal of Cereal Science 45, 238-247.

Martins JM, Riottot M, de Abreu MC. 2005. Cholesterollowering effects of dietary blue lupin (Lupinus angustifolius L.) in intact and ileorectal anastomosed pigs. J. Lipid Res. 46, 1539-47.

Megraw R, Dunn D, Biggs H. 1979. Mannual and continuous flow colorimetry of triglycerols by a fully enzymaic method. Clin. Chem. 25, 273-284.

Monfort MT, Trovato A, Kirjaainen S, Forestieri AM, Galati EM, Curto RB. 1995. Biological effects of hesperidin, a citrus flavonoids. (Note II): Hypolipidemia activity on experimental hypercholesterolemia in rat. Farmaco 50, 595-599.

Morcos SR. 1967. The effect of protein value of the diet on the neurological manifestations produced in rats by $\beta$-immodipropionitrile. Br. J. Nutr. 21, 269 - 274.

Olmo N, Turnay J, Perez-Ramos P, Lecona E, Barrasa JI, de Silanes IL, Lizarbe MA. 2007. In vitro models for the study of the effect of butyrate on human colon adenocarcinoma cells. Toxicology in Vitro 21, 262-270.

Park SY, Park SH, Jeon SM, Park YB, Lee SJ, Jeong TS, Choi MS. 2002. Effect of rutin and tanic acid supplements on cholesterol metabolism in rats. Nutr. Res. 22, 293-295. 
Pereira MA, Ludwig DS. 2001. Dietary fiber and bodyweight regulation. Observations and mechanisms. Pediatr. Clin. North Am. 48, 969-80.

Prior RL. 2003. Fruits and vegetables in the prevention of cellular oxidative damage. Am. J. Clin. Nutr. 78, 570S-578S.

Reitman S, Frankel S. 1957. Calorimetric methods for aspartate and alanine aminotransferase. Am. J. Clin. Path. 28, 55-60.

Rice-Evans CA, Miller NJ, Paganga G. 1997. Antioxidant properties of phenolic compounds. Trends in Plant Science 2, 152-159.

Roberts CK, Barnard RJ, Sindhu RK, Jurczak M, Ehdaie A, Vaziri ND. 2006. Oxidative stress and dysregulation of $\mathrm{NAD}(\mathrm{P}) \mathrm{H}$ oxidase and antioxidant enzymes in dietinduced metabolic syndrome. Metabolism 55, 928-934.

Rouzaud G, Rabot S, Ratcliffe B, Duncan A.J. 2003. Influence of plant and bacterial myrosinase activity on the metabolic fate of glucosinolates in gnotobiotic rats. Br. J. Nutr. 90, 395-404.

Scott KJ. 2001. Detection and measurements of carotenoids by UV/VIS spectrophotometry. In: Current protocols in food analytical chemistry. John Wiley and Sons, Inc, New York. p. F2.2.1-F2.2.10.

Singleton VL, Rossi JA. 1965. Colorimetry of total phenolics with phosphomolybdic-phosphotungstic acid reagents. Am. J. Enol. Vitic. 16, 144-158.

Slavin JL, Martini MC, Jacobs DR, Marquart L. 1999. Plausible mechanisms for the protectiveness of whole grains. Am. J. Clin. Nutr. 70, 459S-463S.

Slavin JL, Jacobs D, Marquart L, Wiemer K. 2001. The role of whole grains in disease prevention. Journal of the American Dietetic Association 101, 780-785.

Son S, Lewis BA. 2002. Free radical scavenging and antioxidative activity of caffeic acid amide and ester analogues: structure-activity relationship. J. Agric. Food Chem. 30, 468-472.

Sosulski F, Krygier K, Hogge L. 1982. Free, esterified, and insolublebound phenolic acids. 3. Composition of phenolic acids in cereal and potato flours. J. Agric. Food Chem. 30, 337-340.

Stucchi AF, Terpstra AHM, Nicolosi RJ. 1995. LDL receptor activity is down-regulated similarly by a cholesterol-containing diet high in palmitic acid or high in Lauric and myristic acids in cynomolgus monkeys. J. Nutr. 125, 2055-2063.

Suido H, Tanaka T, Tabei T, Takeuchi A, Okita M, Kishimoto T, Kasayama S, Higashino K. 2002. A mixed green vegetable and fruit beverage decreased the serum level of low-density lipoprotein cholesterol in hypercholesterolemic patients. J. Agric. Food Chem. 22, 3346-50.

Tholstrup T, Marckmann P, Vessby B, Sandstrom B. 1995. Effect of fats high in individual saturated fatty acids on plasma lipoprotein a levels in young healthy men. J. Lipid Res. 36, 1447-52.

Thompson LU. 1994. Antioxidants and hormonemediated health benefits of whole grains. Critical Reviews in Food Science and Nutrition 34, 473-497.

Toro G, Ackerman PG. 1975. Practical Clinical Chemistry, $1^{\text {st }}$ edition, Little, Brown and Company, Boston USA, pp.352-359.

Velioglu YS, Mazza G, Gao L, Oomah BD. 1998. Antioxidant activity and total phenolics in selected fruits, vegetables, and grain products. J. Agric. Food Chem. 46, 4113-4117.

Venn BJ, Mann JI. 2004. Cereal grains, legumes and diabetes. Eur. J. Clin. Nutr. 58, 1443-1461.

Warnholtz A, Mollnau H, Oelze M, Wendt M, Munzel T. 2001. Antioxidants and endothelial dysfunction in hyperlipidemia. Current Hypertension Reports 3, 5360.

Watson D. 1960. A simple method for the determination of serum cholesterol. Clin. Chem. Acta. 5, 637-642.

Zareba G, Serradelf N. 2004. Chemoprotective effects of broccoli and other Brassica vegetables. Drug Future 29, 1097-1104.

Zhou KQ, Yin JJ, Yu LL. 2005. Phenolic acid, tocopherol and carotenoid compositions, and antioxidant functions of hard red winter wheat bran. J. Agric. Food Chem. 53, 3916-3922.

Zielinska-Przyjmska M, Olejnik A, DobrowolskaZachwieja A, Grajek W. 2009. In vitro effects of beetroot juice and chips on oxidative metabolism and apoptosis in neutrophils from obese individuals. Phytother. Res. 23, 49-55.

Zulet MA, Macarulla MT, Portillo MP, Noel-Suberville C, Higueret P, Matinez JA. 1999. Lipid and glucose utilization in hypercholesterolemic rats fed a diet containing heated chickpea (Cicer Aretinum L.): a potential functional food. Int. J. Vitam. Nutr. Res. 69, 403-409. 